\title{
Brown Norway ovalbumin model: temporal profile of cytokines
}

\author{
Janice D Woodhouse, Alan Wilhelm, Michael Caniga, Malgorzata Gil, Jie Zhang-Hoover, Robbie McLeod, \\ Lily $Y$ Moy, Milenko Cicmil
}

From 2nd Cross Company Respiratory Symposium

Horsham, UK. 6-7 September 2012

\section{Background}

The ovalbumin (OVA) sensitized and challenged Brown Norway $(\mathrm{BN})$ rat model is a practical PD model often used to determine the impact of drug treatment on late phase lung inflammation. However, the sole measurement of bronchoalveolar lavage fluid (BALF) inflammatory cells does not always correlate into human efficacy for respiratory diseases such as asthma. Added value to this rodent model may be derived by a deeper understanding of the relationship between disease-related cytokine secretion and inflammation.

\section{Materials and methods}

Animal sensitizations, challenges, and BALF collections were performed as described previously [1]. Inflammatory cell counts and cytokine temporal profile was investigated in BALF samples collected from animals at 6, 24, 48, and 72 hours post whole-body OVA challenge. Effect of orally dosed betamethasone on the temporal profile of inflammatory cells and cytokines was also investigated.

\section{Results}

Differential cell counts from BALF showed an increase in neutrophil levels at $6 \mathrm{~h}$, reaching maximum at $24 \mathrm{~h}$, in OVA challenged animals. The influx of eosinophils in BALF continues to increase with time, reaching peak at 72h. Baseline levels for a panel of cytokines (including IL-13 and IL-5) were also established with most reaching maximal levels at $24 \mathrm{~h}$. A significant inhibition of neutrophil levels was seen in the betamethasone group at $6 \mathrm{~h}$ (71\%) and 24h (67\%) along with inhibition of IL-13 (90\%) at $24 \mathrm{~h}$. Betamethasone was also able to significantly inhibit eosinophilia and IL-13 at $48 \mathrm{~h}$ time point.

Merck Research Laboratories, Boston, MA 02115, USA

\section{Conclusions}

We were able to confirm the temporal profile of cytokine secretion in BALF in this model. In addition, we have shown that betamethasone inhibited both cytokines and cell infiltration in a dose dependent manner. The cytokine endpoint in conjunction with cell influx brings added value to the standard OVA challenged Brown Norway rat model.

Published: 14 August 2013

\section{Reference}

1. Chapman RW, Curran AK, House A, Richard J, Salisbury B, Hunter JC, Anthes JC, Phillips JE: Effect of mometasone furoate (MF)/formoterol fumarate $(F)$ combination (MF/F) on late-phase responses in allergenchallenged Brown Norway rats. Pulm Pharmacol Ther 2011, 24(1):67-73.

doi:10.1186/1476-9255-10-S1-P9

Cite this article as: Woodhouse et al:: Brown Norway ovalbumin model: temporal profile of cytokines. Journal of Inflammation 2013 10(Suppl 1): P9.
Submit your next manuscript to BioMed Central and take full advantage of:

- Convenient online submission

- Thorough peer review

- No space constraints or color figure charges

- Immediate publication on acceptance

- Inclusion in PubMed, CAS, Scopus and Google Scholar

- Research which is freely available for redistribution

Submit your manuscript at www.biomedcentral.com/submit
( Biomed Central

\section{Biomed Central}

(c) 2013 Woodhouse et al; licensee BioMed Central Ltd. This is an Open Access article distributed under the terms of the Creative Commons Attribution License (http://creativecommons.org/licenses/by/2.0), which permits unrestricted use, distribution, and reproduction in any medium, provided the original work is properly cited. 